\title{
CHARACTERIZATION OF INTERPHASE NUCLEI FROM TRIPLOID HYBRIDS BETWEEN Pennisetum purpureum Schumach AND Pennisetum glaucum (L.) R. Br.
}

\author{
Caracterização de núcleos interfásicos de híbridos tríploides entre Pennisetum \\ purpureum Schumach e Pennisetum glaucum (L.) R. Br.
}

\author{
Cristiane Gouvêa Fajardo ${ }^{1}$, Lisete Chamma Davide², Antônio Vander Pereira ${ }^{3}$
}

\begin{abstract}
This study evaluated the structure and the volume of interphase nuclei from root meristems of the genotypes of napier grass (Pennisetum purpureum), pearl millet (Pennisetum glaucum) and hybrids resultant of such breeding. In napier grass, nuclei were areticulate. Both pearl millet and the triploid hybrid had semi-reticulate nuclei; also, the hybrid presented a small proportion (6\%) of areticulate nuclei. Pearl millet had the highest averages of nuclear dimensions, such as volume, diameter and radius, followed by the interspecific hybrid and napier grass. There was no intraspecific variation for the type of nuclear structure, which indicates this feature is important for cytotaxonomic studies involving the genus Pennisetum. Results demonstrated that chromatin organization in these nuclei was influenced by the number and size of chromosomes, affecting the nucleus volume in the analyzed taxa.
\end{abstract}

Index terms: Napier grass, pearl millet, interphase chromatin, nuclear volume.

\section{RESUMO}

Avaliou-se, neste estudo, a estrutura e o volume de núcleos interfásicos de meristemas radiculares de genótipos do capimelefante (Pennisetum purpureum), milheto (Pennisetum glaucum) e do híbrido resultante deste cruzamento. O capim-elefante apresentou núcleos do tipo arreticulado. Tanto no milheto como no híbrido triplóide os núcleos apresentaram-se semi-reticulados, sendo que, no híbrido, foi observada uma pequena proporção $(6 \%)$ de núcleos arreticulados. As maiores médias para as dimensões nucleares como volume nuclear, diâmetro e raio foram obtidas para o milheto, seguidas do híbrido interespecífico e capim-elefante. Não houve variação intraespecífica para tipo de estrutura nuclear indicando que essa característica tem relevância para estudos citotaxonômicos no gênero Pennisetum. Os resultados demonstraram que a organização da cromatina nesses núcleos foi influenciada pelo número e tamanho dos cromossomos e essa afetou o volume nuclear dos táxons analisados.

Termos para indexação: Capim elefante, milheto, cromatina interfásica, volume nuclear.

(Received in june 16, 2009 and approved in february 22, 2010)

\section{INTRODUCTION}

Pennisetum Rich. is one of the most important genera of the Poaceae family. This genus is characterized by its high complexity and heterogeneity due to the many proposed taxonomic arrangements, including approximately 140 species distributed along a wide tropical zone of the planet (Jauhar \& Hanna, 1998). Considering its several species, great emphasis has been given to pearl millet (Pennisetum glaucum $(2 \mathrm{n}=2 \mathrm{x}=14)$, which is used as cereal in human diet or as forage, as well as to napier grass Pennisetum purpureum $(2 \mathrm{n}=4 \mathrm{x}=28)$, due to its importance as forage.

The production of hybrids between these two species has been a common and routine strategy of the napier grass improvement program to obtain more productive progenies of higher nutritional quality. Such hybridization results in the production of a sterile triploid hybrid $(2 n=3 x=21)$, which requires a chromosomal duplication to recover fertility and make viable the use of this hybrid combination in improvement programs. Attempts of chromosomal duplication have led to the production of both hexaploid and mixoploid plants due to chromosomal elimination (Abreu et al., 2006; Barbosa et al., 2007; Campos et al., 2009).

The combination between two parental genomes in the nucleus of interspecific hybrids may result in intergenomic conflicts, leading to genetic and epigenetic reorganizations (Riddle \& Birchler, 2003), which frequently cause specific elimination of DNA sequences already in the first stages after hybridization (Liu et al., 1996; Feldman et al., 1997), as observed in napier grass and pearl millet hybrids (Campos et al., 2009). Such changes can be understood as a response of the genome to a new situation (Levin, 2002).

\footnotetext{
${ }^{1}$ Federal University of Lavras/UFLA - Cx. P. 3037 - 37.200-000 - Lavras, MG - genegoista@yahoo.com.br ${ }^{2}$ Federal University of Lavras/UFLA - Departament of Biology - Lavras, MG ${ }^{3}$ Empresa Brasileira de Pesquisa Agropecuária/Embrapa - Juiz de Fora, MG
} 
Considering the alterations that may occur in the hybrid nucleus, this work aimed to characterize the volume and structure of interphase nuclei of the genotypes of napier grass, pearl millet and hybrids resultant of such breeding.

\section{MATERIAL AND METHODS}

Two triploid hybrids resultant of the breeding between napier grass (Pennisetum purpureum Schum.) and pearl millet [Pennisetum glaucum (L.) R. Br.] were evaluated, as well as their respective genitors. The used genotypes belong to the Active Germplasm Database of Dairy Cattle Embrapa, in the city Juiz de Fora, State of Minas Gerais, Brazil.

Interphase nuclei were analyzed in slides prepared from meristems extracted from cuttings or germinated seeds. The roots were fixed with methanol:acetic acid 3:1 and subjected to enzymatic maceration using Pectinase/ Cellulase solution $(40 \%$ / 4\%). Slides were mounted through cell dissociation, air-dried (Carvalho \& Saraiva, 1993), and stained with $10 \%$ Giemsa solution in phosphate buffer $\mathrm{pH}$ 6.8 for 5 minutes.

To classify and evaluate the interphase nuclear volume (INV), ten slides per genotype were analyzed, and for each slide ten nuclei were evaluated in random fields, totalizing 100 interphase nuclei per studied taxon and per evaluated feature.
Interphase nuclei were classified according to the nomenclature proposed by Guerra (1987).

For INV evaluation, the largest measures were used, and their mean was considered the interphase nucleus mean diameter. Then, the final radius was obtained. To calculate the nuclear volume, the following formula was employed: $4 / 3 \pi r^{3}$, where ' $r$ ' is the nuclear radius used for volume calculation (Das \& Mallick, 1993).

The original data for radius, diameter and nuclear volume were log transformed in order to obtain the normal distribution and carry out statistical analyses. Means were grouped by the Scott Knott test (Scott \& Knott, 1974), at 5\% significance.

\section{RESULTSAND DISCUSSION}

According to the classification proposed by Guerra (1987), interphase nuclei in napier grass are areticulate, with fused chromocenters and irregular shape (Figure 1A). Pearl millet nuclei were classified as semi-reticulate, with strongly stained and slightly polarized chromatic reticulum besides irregular chromocenters (Figure 1B).

The triploid interspecific hybrid had interphase nuclei similar to those of the parental pearl millet. However, nuclei similar to those of napier grass were rare, at a proportion of $6 \%$ nuclei (Figures $1 \mathrm{C}$ and D).

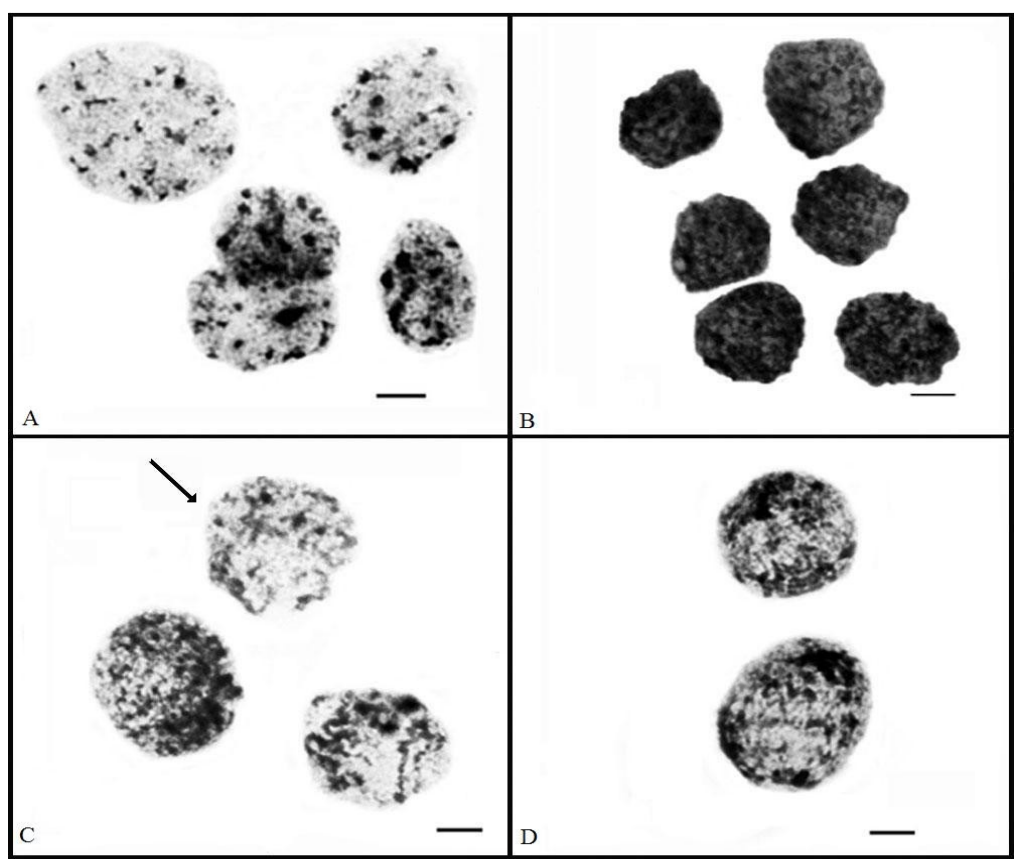

Figure 1 - Interphase nuclei. A - areticulate nuclei from napier grass; B - semi-reticulate nuclei from pearl millet; C semi-reticulate and areticulate nuclei (arrow) from the interspecific hybrid; D - semi-reticulate nuclei from the interspecific hybrid. Bar $=10 \mu \mathrm{m}$. 
The present results agree with those reported by Guerra (1987, 2000) concerning chromosome size. According to that author, species presenting chromosomes with length inferior to $3 \mu \mathrm{m}$, such as napier grass (Barbosa et al., 2003), generally have areticulate nuclei containing condensed chromatin. In species presenting median chromosomes, ranging from $3 \mu \mathrm{m}$ to $5 \mu \mathrm{m}$ length, such as pearl millet (Barbosa et al., 2003), the heterochromatin is irregularly distributed and the nuclei are semi-reticulate. For Barlow (1977) such correlation is more evident between DNA content and the interphase nucleus type. However, flow cytometry analyses indicated that napier grass and pearl millet have similar DNA content values (Martel et al., 1997) and the triploid interspecific hybrid presents lower DNA content than its parental species, which is due to sequence eliminations (Campos et al., 2009).

Besides chromosome size, other factors may interfere with chromatin organization in the interphase nucleus, including distribution of repetitive sequences, heterochromatin quantity and distribution, condensation pattern in the prophase, and nuclear DNA content (Guerra, 1984, 1987). It is already established that there is a strong correlation between the genome structural organization and the gene expression control (Verschure, 2004).

For napier grass and pearl millet, besides the already cited features, differences in the chromosome number could be another factor of structural differences between their nuclei, since napier grass is tetraploid $(2 \mathrm{n}=4 \mathrm{x}=28)$ and pearl millet is diploid and presents $2 n=2 x=14$ chromosomes.

Intrageneric variation concerning the nucleus type is rare; however, it has already been observed in other genera as Tillandsia and Nicotina (Gauthé, 1965; Gross, 1965; Merrit, 1974; Guerra, 1987). Such variation in the classification of napier grass and pearl millet nuclei highlights the importance of this feature as a parameter for cytotaxonomic purposes concerning Pennisetum species, as there was no intraspecific variation for nucleus type.
Further studies involving other species of this genus can confirm the importance of the interphase nuclear structure in species differentiation, which could contribute to identify accesses to germplasm databases, since many times the material collected in the field is incorrectly classified.

In the case of the interspecific hybrid, the mixture between nucleus types in the same tissue allows the confirmation of hybridization and can explain the production of a large number of mixoploids when these hybrids were subjected to polyploidization through antimitotic agents. The different stages in which cells are found at the moment of induction, the different division times of two parental species, and the rearrangements that occur after the gathering of different genomes are known to contribute to mixoploid production; however, the presence of two nucleus types, already in the material that is going to be duplicated, is another factor that must be considered.

As regards nuclear measures, the $\mathrm{F}$ test following analysis of variance was significant $(\mathrm{P} \leq 0.01)$ for all evaluated features, indicating there are differences between the studied Pennisetum sp. genotypes (Table 1). According to the Scott-Knott test, the mean values of radius, diameter and nuclear volume were higher for pearl millet, followed by the triploid hybrid and, finally, napier grass (Table 2).

Such results do not correlate to the DNA content of these taxa. As previously cited, napier grass and pearl millet had similar DNA content, which in the triploid interspecific hybrid is inferior to that of the parental species (Martel et al., 1997). These values could be explained by the chromatin arrangement in the interphase nucleus in the case of parental species, as well as by the presence of different nucleus type in the hybrid's meristem.

Therefore, for the studied Pennisetum taxa, the number and size of chromosomes influence the interphase nucleus structure, which probably affects the nuclear volume.

Table 1 - Analysis of variance for the parameters radius, diameter and volume of interphase nuclei from pearl millet, napier grass and the triploid hybrid.

\begin{tabular}{lllll}
\hline \multirow{2}{*}{ SV } & \multicolumn{4}{c}{ Mean Squares } \\
\cline { 2 - 5 } & DF & Radius $(\mu \mathrm{m})$ & Diameter $(\mu \mathrm{m})$ & ${\text { Volume }\left(\mu \mathrm{m}^{3}\right)}$ \\
\hline Treatment & 2 & $0.286318^{* *}$ & $0.291985^{* *}$ & $2.576080^{* *}$ \\
Error & 297 & 0.008669 & 0.008537 & 0.078078 \\
Total & 299 & & & 8.31 \\
CV & & 10.19 & 7.60 &
\end{tabular}

**: $\mathrm{F}$ test significant at $1 \%$ probability. 
Table 2 - Mean values for the parameters radius, diameter and volume of interphase nuclei from pearl millet, napier grass and the triploid hybrid.

\begin{tabular}{lccc}
\hline GENOTYPES & $\begin{array}{c}\text { Radius } \\
(\mu \mathrm{m})\end{array}$ & $\begin{array}{c}\text { Diameter } \\
(\mu \mathrm{m})\end{array}$ & $\begin{array}{c}\text { Volume } \\
\left(\mu \mathrm{m}^{3}\right)\end{array}$ \\
\hline Napier grass & $7.33 \mathrm{c}$ & $14.64 \mathrm{c}$ & $1863.11 \mathrm{c}$ \\
Triploid hybrid & $8.53 \mathrm{~b}$ & $17.07 \mathrm{~b}$ & $2926.11 \mathrm{~b}$ \\
Pearl millet & $9.38 \mathrm{a}$ & $18.77 \mathrm{a}$ & $3930.89 \mathrm{a}$ \\
\hline
\end{tabular}

* Means followed by the same letters in the column do not differ at $5 \%$ probability (Scott-Knott).

\section{CONCLUSIONS}

The interphase nuclear structure in napier grass (areticulate) differs from that in pearl millet (semi-reticulate), and the interspecific hybrid presents a mixture between the parental nucleus types, with higher proportion of semireticulate nuclei. Chromatin organization in these nuclei was influenced by the number and size of chromosomes, affecting the nuclear volume of the analyzed taxa.

\section{ACKNOWLEDGEMENTS}

The authors are grateful to the Research Foundation of the State of Minas Gerais (FAPEMIG), for the financial support to the development of this work, and to the National Council for Scientific and Technological Development (CNPq), for the scholarship to the first author.

\section{REFERENCES}

ABREU, J.C.; DAVIDE, L.C.; PEREIRA, A.V.; BARBOSA, $\mathrm{S}$. Mixoploidia em híbridos de capim-elefante $\mathrm{x}$ milheto tratados com agentes antimitóticos. Pesquisa Agropecuária Brasileira, Brasília, v.41, n.11, p.16291635,2006

BARBOSA, S.; DAVIDE, L.C.; PEREIRA, A.V. Cytogenetic of Pennisetum purpureum Schumach. x Pennisetum glaucum L. hybrids and their parents. Ciência e Agrotecnologia, Lavras, v.27, n.1, p.26-35, 2003.

BARBOSA, S.; DAVIDE, L.C.; PEREIRA, A.V.; ABREU, J.C. Duplicação cromossômica em híbridos triplóides de capim-elefante e milheto. Bragantia, Campinas, v.66, p.365-372, 2007.

BARLOW, P. Determinants of nuclear chromatin structure in angiosperms. Annual Scientific Natural, Botany, Paris, v.18, p.193-206, 1977.
CAMPOS, J.M.S.; DAVIDE, L.C.; SALGADO, C.C.; SANTOS, F.C.; COSTA, P.N.; SILVA, P.S.; ALVES, C.C.S.; VICCINI, L.F.; PEREIRA, A.V. In vitro induction of hexaploid plants from triploid hybrids of Pennisetum purpureum and Pennisetum glaucum. Plant Breeding, Berlin, v.128, p.101-104, 2009.

CARVALHO, C.R.; SARAIVA, S. An air drying technique for maize chromosomes without enzymatic maceration. Biotechnic \& Histochemistry, London, v.68, p.142-145, 1993.

DAS, A.B.; MALLICK, R. Karyotype diversity and interspecific 4C DNA variation in Bupleurum. Biologia Plantarum, Calcutta, v.35, p.355-363, 1993.

FELDMAN, M.; LIU, B.; SEGAL, G.; ABBO, S.; LEVY, A.A.; VEGA, J.M. Rapid elimination of low-copy DNA sequences in polyploid wheat: A possible mechanism for differentiation of homoeologous chromosome. Genetics, Balmotire, v.147, p.1381-1387, 1997.

GAUTHÉ, Z. Contribuition a l'étude caryologique des Tillandesiées. Mémoires du Muséum National d'Histoire Naturelle, Botanique, Paris, v.16, p.39-59, 1965.

GROSS, J.P. Contribuition a l'étude caryologique dês Pittosporacées. Mémoires du Muséum National d'Histoire Naturelle, Botanique, Paris, v.16, p.61-90, 1965.

GUERRA, M. Patterns of heterochromatin distribution in plant chromosomes. Genetics and Molecular Biology, Ribeirão Preto, v.23, n.4, p.10291041, 2000.

GUERRA, M.S. Cytogenetics of rutaceae: IV., struture and systematic significance of interphase nuclei. Cytologia, Tokyo, v.52, p.213-222, 1987.

GUERRA, M.S. New chromosome number in Rutaceae. Plant Systematics and Evolution, Viena, v.146, n.1/2, p.13-30, 1984.

JAUHAR, P.P.; HANNA, W.W. Cytogenetics and genetics of pearl millet. Advances in Agronomy, New York, v.64, p.1-26, 1998. 
LEVIN, D.A. The role of chromosomal change in plant evolution. New York: Oxford University, 2002. 230p.

LIU, S.C.; KOWALSKI, S.P.; LAN, T.H.; FELDMAN, K.A.; PATERSON, A.H. Genome-wide high-resolution mapping by recurrent intermating using Arabidopsis thaliana as a model. Genetics, Balmotire, v.142, p.247258, 1996.

MARTEL, E.; NAY, D.; SILJAK-YAKOVIEV, S.; BROWN, S.; SARR, A. Genome size variation and basic chromosome number in pearl millet and fourteen related Pennisetum species. The Journal of Heredity, Washington, v.88, n.2, p.139-143, 1997.
MERRITT, J.F. The distribution of heterochromatin in genus Nicotiana (Solanaceae). American Journal Botany, Columbus, v.61, p.982-994, 1974.

RIDDLE, N.C.; BIRCHLER, J.A. Effects of reunited diverged regulatory hierarchies in allopolyploids and species hybrids. Trends in Genetics, London, v.19, n.11, p.597-600, 2003.

SCOTT, A.J.; KNOTT, M. A cluster analysis method for grouping means in the analysis of variance. Biometrics, Washington, v.30, p.507-512, 1974.

VERSCHURE, P.J. Positioning the genome within the nucleus. Biology of the Cell, Amsterdam, v.96, p.569-577, 2004. 